\title{
Economic Evaluation of Leaf and Pod Yields of Fluted Pumpkin (Telfairia occidentalis) Produced by Five Different Staking Methods.
}

\author{
${ }^{1}$ Enujeke, E. C. \\ ${ }^{I}$ Department of Agronomy, Delta State University, Abraka Campus, Asaba.
}

\begin{abstract}
This study was carried out in the Teaching and Research Farm of Delta State University, Asaba Campus in 2005 and repeated in 2006 to conduct an economic evaluation of leaf and pod yields of Telfairia occidentalis produced by five different staking methods replicated three times in a Randomized Complete Block Design (RCBD). Data collected were subjected to analysis of variance and significant means were separated using Least Significant Difference (L.S.D). The results of obtained indicated a positive influence of staking on yield and yield components of Telfairia occidentalis. Leaf and pod yields were better under staking than when the crop was allowed to creep on the ground. Based on the findings of the study, raised platform method, which had the highest values with respect to leaf yield, pod yield, market values and benefit cost ratio, was recommended to farmers in the study area.
\end{abstract}

Keywords: Economic Evaluation, Leaf and Pod Yields, Fluted Pumpkin Staking Methods, Asaba Nigeria.

\section{Introduction}

Fluted pumpkin (Telfairia occidentalis) is one of the most popular cucurbitaceous leaf and seed vegetables grown for human consumption. It is a high climbing perennial with partial drought tolerance and perenating root system (Egun, 2007). It is native to West Africa but occurs mostly in its cultivated form in various parts of Southern Nigeria where the leaves (which produce strong aroma), succulent shoots and seed kernel constitute valuable ingredients in soups (Akoroda et al., 1990) Nwanguma (1990) reported that Telfairia occidentalis (Ugu) is an important vegetable noted for its nutrient and flavour components.

In spite of the increasing relevance and high demand for Telfairia occidentalis in Nigeria, there is no standard practice with respect to staking. In large farms and near the cities, the crop is often left to creep on the ground with its attendant problems of pest and disease infestation, and splash of sand on the marketable yield due to torrential rains. Traditional farmers stake Telfairia occidentalis for increased yield. Some researchers also stake the crop for better exposure to sunlight, ventilation and good yield.

Egun (2007) recommended staking of Telfairia occidentalis for enhanced marketable leaf yield.

Borget (1992), Kwarteng and Towler (1994) suggested that the climbing species such as Telfairia occidentalis should be supported with bush sticks to enhance growth and development.

Okonmah (2011), recommended raised platform staking method for increase pod yield, enhanced market value, higher estimated revenue for such climbing vegetables as cucumber and Telfairia occidentalis.

Amina et al., (2012) recommended staking of tomatoes and other fruit crops for higher yield, and good quality fruits with higher market value. Akoroda et al., (1990) suggested staking of crops to facilitate harvesting of vegetables and pods, and exposure of leaves for effective light reception. FAO (2007) reported that staking increases fruit yield, reduces the proportion of unmarketable fruit, enhances the production of high quality fruits, prevents disease and fruit rot, allows better aeration and exposes better exposure of the foliage to sunlight and photosynthetic activities. However, unavailability of staking materials and high cost of staking around cities necessitates research work into the most economical method of achieving highest yield at reduced cost. The objectives of this study therefore were to:

(i) Assess the influence of various types of staking methods on the leaf and pod yields of Telfairia occidentalis.

(ii) Conduct an economic evaluation with a view to identifying the cheapest technology in Telfairia production.

\section{Materials and Methods}

Site Description: The experiment was carried out in the Teaching and Research Farm of Delta State University, Asaba Campus from March to July, 2005 and repeated between March and July, 2006. Asaba is located at $06^{\circ} 14 \mathrm{~N}$ of the equator. It lies in the tropical rainforest zone and is characterized by rainy season between April and October with annual mean rainfall of 1500 to $3000 \mathrm{~mm}$ (FOS, 1996).

Land preparation: The gross area $\left(540 \mathrm{~m}^{2}\right)$ was cleared using cutlass, and burnt in the month of March, 2005. Tillage was carried using hoe while plots measuring $5 \mathrm{~m} \mathrm{x} 5 \mathrm{~m}\left(25 \mathrm{~m}^{2}\right)$ were marked out. The net area used for the experiment was $375 \mathrm{~m}^{2}$, while discards totaled $165 \mathrm{~m}^{2}$. 
Pre-planting soil Analysis: Surface sols $(10-15 \mathrm{~cm})$ were sampled with a tabular sampling auger. Representative soil samples were taken and then bulked together from the replicate. The samples were air-dried at room temperature for 5 days and crushed to pass through a $2 \mathrm{~mm}$ mesh tube. Sub - samples from the bulked soil sample were further ground to pass through 100 -mesh sieve for the determination of organic matter. The rest samples were then analyzed to determine the physical and chemical properties of the soil. The analysis was done at Nigeria Institute for Oil Palm Research (NIFOR), Benin City, Edo State.

Particle Size: The analysis was done by the hydrometer method of Bouyoucos (1951) after destroying the organic matter with hydrogen peroxide and dispersing the soil with sodium hexarnetaphosphate.

pH: This was determined in distilled water and in INKCL in a 1:1 soil-to-solution suspension using a pH meter. Organic Matter: This was determined from the result of organic carbon as follows: \% organic mailer in the soil $\%$ organic carbon $\mathrm{x} 1.79$. The total nitrogen $(\mathrm{N})$ content of the soil then calculated from the result of the $\%$ organic matter as follows:

Total $\mathrm{N}=5 \%$ of result organic matter content in the soil (I1TA, 1979).

Exchangeable Bases: The soil was extracted with neutral NH.OAC. $\mathrm{K}$ and $\mathrm{Na}$ in the extracts were determined by flame photometry and $\mathrm{Mg}$ by the atomic absorption spectrophotorneter.

Total Exchangeable Acidity: This was extracted with INKCL and estimated in the extracts by titration method (McClean. 1965).

Effective Cation Exchange Capacity (ECEC): This was taken as the sum of the exchangeable bases and exchange acidity (E.A) (Brady and Weils, 1999).

\section{Seed Collection, Planting, Staking and Manure Application}

Seeds of Telfairia occidentalis were obtained from pods collected from proven varieties among farmers, and pre-germinated in well-decomposed seedbed nursery with good topsoil to enhance field establishment. The seedlings were transplanted to the plots after 2 weeks from sowing in the nursery. One seedling was planted per stand at a spacing of $1 \mathrm{~m}$ apart, which gave plant population of 25 plants per plot. Two weeks after transplanting, the seedlings were staked according to the treatments. Well-decomposed organic manure was applied at the rate of 0.0005 ton per plant.

\section{Experimental Design}

The experiment was set up in a Randomized Complete Block Design (RCBD) replicated three times with five treatments involving different staking methods. (i) Without Staking (ii) Raised Platform (iii) Erect (3 m) Staking (iv) Dwarf (1m) Staking (v) Bamboo tip staking.

\section{Data Collection and Analysis}

Fifteen plants were sampled per treatment of 25 stands and about $50 \mathrm{~cm}$ length harvested from each. Using a weighing scale, edible yield (the leaf and the succulent stem) of the treatments were also weighed at fortnight intervals starting from the $12^{\text {th }}$ week after planting. At maturity (33 weeks old), the pod yield of each treatment were determined. The results obtained were subjected to analysis of variance. Treatment means were separated using Least Significant Difference (L.S.D).

\footnotetext{
III. Results

Physico-chemical properties of the experimental site

The phvsico-chemical properties of the study area is shown in Table 1 . The soil was predominantly sandy. The surface had more sand than the subsurface. Texturally, the experimental site was classified as sandy clay. The soil is generally acidic with a $\mathrm{pH}$ of 5.7. The organic matter and total nitrogen content were low with values of $0.12 \mathrm{gkg}$ ' and $0.05 \mathrm{gkg}-1$, respectively. The available $P$ was equally low with a value of $9.3 \mathrm{mgkg}$. The exchangeable cations were low in status with values of $1.86 \mathrm{cmol}$ ( $\mathrm{kg}$ for $\mathrm{Ca}$ and $1.42 \mathrm{crnolkg}$ ' for $\mathrm{Mg}$. The values obtained for K $(0.07 \mathrm{cmolkg}$ ') and ECEC $(8.45 \mathrm{cmolkg}$ ') were low. This could be attributed to low activity clay of the study area while the low values obtained Organic C, total Nitrogen and P were as a result of erosion that is predominant in the area and subsequent leaching of the nutrient beyond the root zone.
} 
Table 1: Physico-chemical properties of the experimental site

\begin{tabular}{ll}
\hline Soil properties & Value \\
\hline Particles size distribution (\%) & 66.3 \\
Sand & 26.3 \\
Silt & 7.4 \\
Clay & \\
Textural class sandy clay & 5.7 \\
Soil pH $\left(\mathrm{H}_{2} 0\right)$ & 0.05 \\
Org. C $\left(\mathrm{g} \mathrm{Kg}^{-1}\right)$ & 0.12 \\
Total N $\left(\mathrm{gkg}^{-1}\right)$ & 9.3 \\
Available P $\left(\mathrm{mgkg}^{-1}\right.$ soil) & \\
Exchangeable cations $\left.(\mathrm{cmol} \mathrm{kg})^{-1}\right)$ & 1.86 \\
Ca & 1.42 \\
Mg & 0.07 \\
$\mathrm{~K}$ & 0.12 \\
$\mathrm{Na}$ & 8.45 \\
ECEC $(\mathrm{cmol} \mathrm{kg}$ & \\
Base saturation $(\%)$ & 41.1 \\
\hline
\end{tabular}

Legend: $\quad \%=$ Percentage, $\mathrm{H}_{2} \mathrm{O}=$ Water, Org. $\mathrm{C}=$ Organic carbon, $\mathrm{gkg}^{-1}=$ gram per kilogram, $\mathrm{N}=$ Nitrogen, $\mathrm{P}=$ Phosphorus, mgkg-1 = Milligram per kilogram, $\mathrm{cmol} \mathrm{kg} \mathrm{k}^{-1}=$ centimole per kilogram, $\mathrm{Ca}=$ Calcium, $\mathrm{Mg}=$ Magnesium, $\mathrm{K}=$ Potassium, $\mathrm{Na}=$ Sodium, $\mathrm{ECEC}=$ Exchangeable Cation Exchange Capacity.

Total Market Value and Estimated Revenue from Cumulative Leaf Yield and total pod yield of Various Staking Methods in $25 \mathrm{~m}^{2}$ Plots in 2005 and 2006.

Total market value and estimated revenue from cumulative leaf yield and total pod yield of various staking methods in 2005 and 2006 are shown in Tables 2 and 3. In 2005 (Table 2), staked plants had the highest values with respect to leaf and pod yields and their market values. Plants grown on raised platform were superior in cumulative leaf yield $(12.15 \mathrm{~kg})$, market value of leaves $(\$ 2,430)$, pod yield $(18.2 \mathrm{~kg})$, market value of pods $(\$ 3,640)$, total market value of produce $(\$ 6,070)$. When the costs of staking and weeding were considered, the Telfairia grown on raised platform was superior $(5,030)$, and had optimum benefit cost ratio (5:1) which is better for farmers. This was followed by bamboo tip staking with pod yield of $15.2 \mathrm{~kg}$, total market value of produce of $(\$ 4,900)$ and estimated revenue of $(\$ 3,650)$. Plants grown without staking had the lowest revenue ( $\$ 2,254)$.

In 2006 (Table 3), the trend did not change plant grown on raised platform had the highest values with respect to cumulative leaf yield $(13.50 \mathrm{~kg})$, market value of leaves $(\$ 2,700)$ pod yield $(19.10 \mathrm{~kg}$ pod), market value of pod $(\$ 3,820)$. Total market value of produce $(\$ 6,520)$, estimated revenue $(\$ 5,480)$, optimum benefit cost ratio of 5:1. Plant grown without staking had the lowest values - Cumulative leaf yield of $8.50 \mathrm{~kg}$, market value of leaves $(\$ 1,700)$, pod yield ( $\$ 3.40 \mathrm{~kg}$ ), market value of pods ( $\$ 680)$, total market value of produce $(\aleph 2,380)$ estimated revenue $(\$ 2,180)$, benefit cost ratio $(11: 1)$.

Table 2. Total market value and estimated revenue from cumulative leaf yield and total pod yield of various staking methods in $25 \mathrm{~m}^{2}$ plot in 2005 .

\begin{tabular}{|c|c|c|c|c|c|c|c|c|c|}
\hline Treatment & $\begin{array}{l}\text { Cumulative } \\
\text { Leaf Yield }\end{array}$ & $\begin{array}{l}\text { Market } \\
\text { Value } \\
\text { Of } \\
\text { Leaves } \\
\end{array}$ & $\begin{array}{l}\text { Pod } \\
\text { Yield }\end{array}$ & $\begin{array}{l}\text { Market } \\
\text { Value } \\
\text { Of Pods } \\
\text { (\#) }\end{array}$ & $\begin{array}{l}\text { Total } \\
\text { Market } \\
\text { Value } \\
\text { (\#) }\end{array}$ & $\begin{array}{l}\text { Cost } \\
\text { Of } \\
\text { Stakin } \\
\text { g } \\
(A)\end{array}$ & $\begin{array}{l}\text { Cost of } \\
\text { weeding }\end{array}$ & $\begin{array}{l}\text { Estimate } \\
\mathrm{d} \\
\text { Revenue } \\
\text { (\#) }\end{array}$ & $\begin{array}{c}\text { Benefit } \\
\text { Cost } \\
\text { Ratio }\end{array}$ \\
\hline Without staking & 8.15 & 1,630 & 3.12 & 624 & 2,254 & 0 & 200 & 2,254 & $11: 1$ \\
\hline Raised Platform & 12.15 & 2,430 & 18.2 & 3,640 & 6,070 & 840 & 200 & 5,030 & $5: 1$ \\
\hline Erect $(3 \mathrm{~m})$ Staking & 6.90 & 1,380 & 12.8 & 3,640 & 3,940 & 1,080 & 200 & 2,660 & $2: 1$ \\
\hline $\begin{array}{l}\text { Dwarf }(1.5 \mathrm{~m}) \\
\text { Staking }\end{array}$ & 9.30 & 1,860 & 8.4 & 1,680 & 3,540 & 675 & 200 & 2,665 & $3: 1$ \\
\hline $\begin{array}{l}\text { Bamboo Tip } \\
\text { Staking }\end{array}$ & 9.30 & 1,860 & 15.2 & 3,040 & 4,900 & 1,050 & 200 & 3,650 & $3: 1$ \\
\hline
\end{tabular}

Market value of leaf $(\mathbb{N})=\$ 200$ per kg

Market value of pod $(\#)=\$ 200$ per kg 
Table 3. Total market value and estimated revenue from cumulative leaf yield and total pod yield of various staking methods in $25 \mathrm{~m}^{2}$ plot in 2006.

\begin{tabular}{|c|c|c|c|c|c|c|c|c|c|}
\hline Treatment & $\begin{array}{l}\text { Cumulativ } \\
\text { e Leaf } \\
\text { Yield }\end{array}$ & $\begin{array}{l}\text { Marke } \\
\mathrm{t} \\
\text { Value } \\
\text { Of } \\
\text { Leave } \\
\quad\end{array}$ & $\begin{array}{l}\text { Pod } \\
\text { Yield }\end{array}$ & $\begin{array}{l}\text { Market } \\
\text { Value } \\
\text { Of Pod } \\
\text { s }\end{array}$ & $\begin{array}{l}\text { Total } \\
\text { Marke } \\
\mathrm{t} \\
\text { Value } \\
\\
(\mathrm{N})\end{array}$ & $\begin{array}{l}\text { Cost Of } \\
\text { Staking }\end{array}$ & $\begin{array}{l}\text { Cost of } \\
\text { weedin } \\
\mathrm{g}\end{array}$ & $\begin{array}{l}\text { Estimate } \\
\mathrm{d} \\
\text { Revenue }\end{array}$ & $\begin{array}{l}\text { Benefit } \\
\text { Cost } \\
\text { Ratio }\end{array}$ \\
\hline Without staking & 8.50 & 1,700 & 3.40 & 680 & 2,380 & 0 & 200 & 2,180 & $11: 1$ \\
\hline Raised Platform & 13.50 & 2,700 & 19.10 & 3,820 & 6,520 & 840 & 200 & 5480 & $5: 1$ \\
\hline Erect (3m) Staking & 7.10 & 1,420 & 13.10 & 2,620 & 4,040 & 1,080 & 200 & 2760 & $2: 1$ \\
\hline $\begin{array}{l}\text { Dwarf }(1.5 \mathrm{~m}) \\
\text { Staking }\end{array}$ & 9.60 & 1920 & 8.8 & 1,760 & 3,680 & 675 & 200 & 2,805 & $3: 1$ \\
\hline $\begin{array}{l}\text { Bamboo Tip } \\
\text { Staking }\end{array}$ & 9.80 & 1960 & 16.4 & 3,280 & 5,240 & 1,050 & 200 & 3,990 & $3: 1$ \\
\hline
\end{tabular}

Market value of leaf $(\mathbb{N})=\$ 200$ per kg

Market value of pod $(\#)=\$ 200$ per kg

\section{Soil hysic-chemical properties ties of the experimental site \\ IV. Discussion}

The sandy texture of the experimental site may be attributed to the Parent Material (PM) from which the soil was formed and the climate of the area. The soil might be formed from sandstone and quartz parent materials. These impart sandy texture to the soils. The high sand content of the soil could be attributed to high content of quartz in the material (Brady and Weils, 1999). The acidic nature of the soil of the area may be traced to the marked leaching of exchangeable bases resulting from the high rainfall associated with the environment and the dissociation of strong and functional group in the organic matter. This is in harmony with the findings of Esu (2001). The low organic matter status of the experimental site could be attributed to the rapid decomposition of organic matter due to high solar radiation and moisture, this favours optimum microbial activities in the soil, It could also be attributed to the annual seasonal bush burning which tend to deplete organic matter accumulation in the soil (Landon,1991).

The low level of total nitrogen could be due to high temperature. It could also be attributed to leaching of' nitrate by torrential rainfall prevalent in the environment (Brady and Weils, 1999). The high level of' Phosphorus may be attributed to either of these reasons: (i) history of land use and cultural practices associated with the land use (that is, cropping of crops that took much $\mathrm{P}$ nutrient from the soil and non application of $\mathrm{P}$ organic fertilizers (Nnaji et al;2002). (ii) The parent material from which the soil was formed may not be too rich in P minerals (Brady and Weils, 1999). (iii) The soil may not be highly acidic as to cause high level of fixation (Brady and Weils, 1999, Isirimah et al; 2003). The low values of exchangeable cations may be attributed to the leaching of bases from the solum due to high rainfall characteristics of the area. The low cation exchange capacity could be attributed to the PM from which the soil was formed, and low organic matter (OM) content of the soil. The PM from which the soil was formed may be poor in basic nutrients. FMANR (1990) noted that soils of the study area was dominated by Fe oxide and Kaolinites. These clay minerals are low in basic cations (Brady and Weils, 1999). The results, generally, are in harmony with the findings of Nnaji et al; (2002) which reported that the history of land use and cultural practices affect soil conditions and crop productivity.

\section{Total Market Value and Estimated Revenue from Cumulative Leaf Yield and total pod yield of Various Staking Methods in $25 \mathrm{~m}^{2}$ Plots.}

Cumulative leaf yield, market value of leaves, pod yield and estimated revenue of plants grown on raised platform staking method were superior to those grown by other staking methods in both years of evaluation possibly because their plants were not only better exposed to sunlight, and photosynthetic activities but had better aeration and disserve free auditions. This is similar to the Findings of Akoroda et al., (1990) and FAO (2007) which reported that such staking method exposes leaves for effective light reception and photosynthetic activities, promotes better aeration, prevents diseases and fruit rot, and reduces the proportion of unmarketable yield. It is also consistent with the reports of Egun (2007), Okonmah (2011) and Amina et al., (2012) which recommended staking of the climbing species for higher leaf and pod yields, good quality fruits, higher market value and enhanced estimated revenue.

Plants that crept on the ground ( those grown without staking) had the highest values with respect to cumulative leaf, pod yield and their market values, and estimated revenue possibly because of the attendant problems of pests and diseases, poor exposure to sunlight, and insufficient ventilation which result in poor growth and development. This is in harmony with the reports of Borget (1992), Kwarteng and Towler (1994) which suggested that the climbing species of plants must not be left to creep on the on ground but be staked with bush sticks to enhance good growth and development. 


\section{Conclusion and Recommendation}

The study was carried out to examine the effects of various staking methods on fluted pumpkin (Telfairia occidentalis). Seven variables were measured to achieve the objectives of the study - leaf yield (edible yield) market value of leaves, pod yield at maturity, market value of pods, total market value of both leaves and pods, costs of staking of various methods, and benefit cost ratio of each staking method.

Based on the results of the study, the following major findings and conclusions were made:

1) Telfairia occidentalis (fluted pumpkin) yielded higher when staked than when allowed to creep on the ground.

2. Raised platform, which had the highest leaf and pod yields, with their corresponding highest market values and optimum benefit cost ratio, proved to be the best method of staking Telfairia occidentalis.

In view of the results and findings of the study, it is recommended that farmers adopt raised platform staking method in production of fluted pumpkin.

\section{References}

[1]. Akoroda, M.O., Ogbechei-Odinaka, N.I., Adebayo, M.I. Ugwu, O.E. Fuwa B. (1990) Flowering, pollination and fruiting in Fluted Pumpkin (Telfairia occidentals) Scientia Horticultura, 43:197-206

[2]. Amina, J.G. Derbew, B, Ali M. (2012). Yield and quality of Indeterminate Tomato (Lycopersicon esculentum Mill) varieties with staking methods in Jimma. Singapore Journal of Scientific Research 2:33-46. Science Alert

[3]. Borget, M. (1992) Food Legumes Macmillan Press, London.

[4]. Bouyoucos, G.H. (1951). A re-calibration of Hydrometer for making mechanical analysis of soils. Agronomy $43: 434$ - 538

[5]. Brady, C. and Weils, R.R. (1999). Nature and properties of Soil Twelfth Edition, Prentice Hall, New Delhi pp $74-114$.

[6]. Egun, A.C. (2007) Comparative Marketable leaf yield of staked and unstaked Pumpkin (Telfairia occidentals) in a Tropical Utisoils. Stud. Home comm. Sci. 1(1) 27-29. Kamia- Raj 2007

[7]. Esu, I.E. (2001) Pedological characterization of soils of Alluvial complex of Nigeria. Ibadan. Pedological handbook 171-190

[8]. F.A.O. (2007) Green Beans integrated pest management. An Ecological Guide Training Resource Text in Crop Development, Major Agronomic Practice, Disease and Insect Ecology, Insect Pest, Natural Enemies and Diseases of Green Bean. Food and Agriculture Organization, Rome, Italy.

[9]. Federal Office of Statistics (FOS) (1996). Annual abstract of statistics (1996) Ed. Lagos, Nigeria.

[10]. IITA (1979) Selected methods for soil and plant analysis. International Institute of Tropical Agriculture. Manual series. No 1

[11]. Isirimah, N.O.; Dickson, A.A. and Igwe C. (2003). Introductory soil Chemistry and Ar Brology for Agriculture and Biotechnology. Asia International Publishers Limited, Port-Harcourt, Nigeria. Pp 103.

[12]. Kwarteng, J.A. and Towler, M.J. (1994) West African Agriculture: A textbook for Schools and Colleges, Macmillan London pp $136-137$

[13]. Landon, J.R. (1991). Brooker tropical soil manual. A handbook for soil survey in the tropics and subtropics. Longman Group. England. 106-144.

[14]. MANR (1990). Literature review of soil fertility. Investigation in Nigeria (in five volume) 3(2) 102-106

[15]. McClean, E.O. (1965). “Alurninwni' in C.A. Black (Ed). Methods of Soil Analysis part 2: 986-994. Agronomy No. 9

[16]. Nnaji, G.U.; Asadu and Mbagwu, J.S.C. (2002). Evaluation of the physico-Chemical properties of soils under selected agricultural land utilization types. Journal of Tropical Agriculture, Food, Environment and Extension 3:27-33. NVUSA

[17]. Nwanguma, E.I. (1990) Diagnostic survey of Plant-parasitic nematodes attacking Telfairia in Nigeria. pp 73-75.

[18]. Okonmah L.U. (2011) Effects of different types of staking and their cost effectiveness on the growth, yield and yield components of cucumber (Cucumis sativa L) International Journal of AgricScience, International Academic Journals, Germany. 